\title{
Multielemental Microanalysis in Root and Leaves, Growth and Biomass in Tomato Seedling in Response to Ca Levels and Induction of Stress: Non-Destructive Spectroscopy
}

\author{
Omar A. Pérez-Dueñas1, Fanny Hernández-Mendoza², Víctor García-Gaytán ${ }^{*}$, \\ Soledad García-Morales ${ }^{3}$ \\ ${ }^{1}$ EI Colegio de Michoacán (LADiPA), La Piedad, Michoacán, Mexico \\ ${ }^{2}$ Colegio de Postgraduados, Campus Montecillo, Texcoco, Estado de México, México \\ ${ }^{3}$ Biotecnología Vegetal, CONACYT-Centro de Investigación y Asistencia en Tecnología y Diseño del Estado de Jalisco, México \\ Email: *vgaytan@colmich.edu.mx, ${ }^{*}$ garvictan@gmail.com
}

How to cite this paper: Pérez-Dueñas, O.A., Hernández-Mendoza, F., García-Gaytán, V. and García-Morales, S. (2021) Multielemental Microanalysis in Root and Leaves, Growth and Biomass in Tomato Seedling in Response to Ca Levels and Induction of Stress: NonDestructive Spectroscopy. Open Journal of Applied Sciences, 11, 672-683.

https://doi.org/10.4236/ojapps.2021.116049

Received: May 21, 2021

Accepted: June 21, 2021

Published: June 24, 2021

Copyright $\odot 2021$ by author(s) and Scientific Research Publishing Inc. This work is licensed under the Creative Commons Attribution International License (CC BY 4.0).

http://creativecommons.org/licenses/by/4.0/

\begin{abstract}
Tomatoes are one of the main vegetables in the food industry that are consumed fresh and processed. A multi-element microanalysis was performed with the use of scanning electron microscopy (SEM) in conjunction with energy dispersion spectroscopy (EDS), to see changes in nutrient concentration in roots and leaves, as well as fresh and dry biomass in tomato seedlings. Exposed in nutrient solution (NS) with different levels of $\mathrm{Ca}$ (control, 25, 50 and $100 \mathrm{mM}$ ). The root was put in also to $\mathrm{H}_{2} \mathrm{O}_{2}$ for 8 hours to observe the changes that occurred. It was observed that NS with $100 \mathrm{mM} \mathrm{Ca}$ in fresh stem biomass and fresh leaf biomass increased by $25 \%$ and $38 \%$ compared to the control. It was observed that the NS with 100 and $50 \mathrm{mM}$ of Ca, the content of $\mathrm{Ca}$ and $\mathrm{Cl}$ in foliar tissue increased by $34.50 \%$ and $13.15 \%$ compared to the control. Treatment with $\mathrm{H}_{2} \mathrm{O}_{2}$ and with 25 and $100 \mathrm{mM}$ of $\mathrm{Ca}$ at NS increased the height of the seedling and fresh leaf bio-mass by $19.75 \%$ and $60.80 \%$ compared to the control. The treatment with $\mathrm{H}_{2} \mathrm{O}_{2}$ and with the different levels of $\mathrm{Ca}$ in the NS increased the content of $\mathrm{C}, \mathrm{P}, \mathrm{K}, \mathrm{Ca}$ and $\mathrm{Cl}$ in the leaf tissue. Only $\mathrm{S}$ was significant for the control. Treatment with $\mathrm{H}_{2} \mathrm{O}_{2}$ and 100 $\mathrm{mM} \mathrm{Ca}$ in the NS increased $\mathrm{Ca}$ and $\mathrm{Mg}$ by $83.48 \%$ and $40.47 \%$ for the root compared to the control. The $\mathrm{K}$ and $\mathrm{Cl}$ in the root was higher in the control treatment by $47.61 \%$ and $55 \%$ respect to the highest level of Ca. It is concluded that multielemental microanalysis is a powerful, non-destructive, fast and accurate tool for the determination of plant nutrients. Also, it is applica-
\end{abstract}


ble for the areas like horticulture, physiology and agronomy.

\section{Keywords}

Microanalysis, Nutrient Solution, Calcium, Root, Leaves, Stem

\section{Introduction}

Hydroponic systems have been used as one of the standard methods for plant biology research and for the commercial production of vegetables such as tomatoes. In addition, it has served to study the responses of plants to biotic and abiotic stress [1]. Tomato seedlings with a good root system will allow a good anchorage to the substrate. Abiotic stress factors, such as salinity, affect the uniformity and nutrition of the tomato [2] [3]. Root pretreatment with hydrogen sulfide $\left(\mathrm{H}_{2} \mathrm{~S}\right)$ protects strawberry plants against salt stress $(\mathrm{NaCl})$ [4]. The exposure of Populus $\mathrm{x}$ capeskins hydroponically to $\mathrm{Cd}$ and $\mathrm{H}_{2} \mathrm{O}_{2}$ showed that the first agent inhibited the antioxidant enzymes. The peroxide caused the accumulation of GSH and the loss of ascorbate [5]. In another study, the immersion of the roots of strawberries (Fragaria x ananassa Dusch.) in $\mathrm{H}_{2} \mathrm{O}_{2}$ increased plant growth, the concentration of photosynthetic pigments, the relative water content in leaves and antioxidant activity [6]. For the previous cases, the exposure of $\mathrm{H}_{2} \mathrm{O}_{2}$ in roots increased the resistance of the plants to salinity stress. In another study, the addition of $10 \mathrm{mM} \mathrm{H}_{2} \mathrm{O}_{2}$ induced nitric oxide production in Mung Bean (Phaseolus aureus) [7]. However, previous investigations did not determine the nutritional profile. Plant nutrition studies are carried out using methods that require chemical extraction to determine an element [8], such as total $\mathrm{N}$ [9] [10] and organic C [11] [12]. Equipment such as plasma spectrometry (ICP-MS), or atomic absorption spectroscopy, several elements are analyzed at the same time in plant nutrition [13] [14] [15] [16]. Experiments are required to demonstrate the accuracy of the data on the nutritional content of plants. We suggest that multielemental microanalysis by SEM/EDS is the adequate, fast, and precise tool for the determination of nutrients in plant tissue.

Scanning electron microscopy with energy dispersive X-ray spectrometry (SEM/EDS) is an elemental microanalysis technique widely applied across a broad range of the physical and biological sciences, engineering, technology, and forensic investigations. Electron-excited characteristic X-ray peaks provide identification and quantification for all elements of the periodic table, with the exceptions of $\mathrm{H}, \mathrm{He}$, and $\mathrm{Li}$ [17] [18]. The previous technique has been used in plant tissue for nutritional diagnosis, to confirm deficiency symptoms or optimal nutritional ranges, in addition, to identify the accumulation of metals in different organs of the plant [19] [20] [21].

In order to evaluate the precision and reliability of the SEM/EDS in the relative content of nutrients. It was experimentally simulated the development of the 
seedlings under two conditions.

Semi-indeterminate growth tomato seedlings Pony Express were exposed hydroponically to different levels of $\mathrm{Ca}$, to see changes in the concentration of nutrients, growth and biomass. As well as the immersion of tomato roots in $\mathrm{H}_{2} \mathrm{O}_{2}$ for 8 hours and find out if it affected the characteristics of the roots and elemental content, root, and leaves. And evaluate the differences in growth, biomass and elemental analysis in each organ of the seedlings using SEM coupled to EDS.

\section{Materials and Methods}

\subsection{Biological Material and Nutrient Solution}

Pony Express $\mathrm{HM}^{\circledR} \mathrm{cv}$ tomato seedlings of semi-indeterminate growth, from Yurecuaro, Michoacanwere used. The roots of the seedling were removed from peat moss using tap water. The experimental units consisted of an airtight container with a capacity of $3.5 \mathrm{~L}^{-1}$, and $2.5 \mathrm{~L}^{-1}$ distilled water was added to each container. Each container contained 20 plants, and five replicates were used. Tomato plants were grown for three weeks in modified Hoagland nutrient solution containing $1.2 \mathrm{mM} \mathrm{KNO}_{3}, 0.8 \mathrm{mM} \mathrm{Ca}\left(\mathrm{NO}_{3}\right)_{2}, 0.2 \mathrm{mM} \mathrm{KH}_{2} \mathrm{PO}_{4}, 0.2 \mathrm{mM}$ $\mathrm{MgSO}_{4}, 50 \mathrm{mM} \mathrm{CaCl}_{2}, 12.5 \mu \mathrm{M} \mathrm{H}_{3} \mathrm{BO}_{3}, 1 \mu \mathrm{M} \mathrm{MnSO}_{4}, 1 \mu \mathrm{M} \mathrm{ZnSO}_{4}, 0.5 \mu \mathrm{M} \mathrm{Cu}-$ $\mathrm{SO}_{4}, 0.1 \mu \mathrm{M}\left(\mathrm{NH}_{4}\right)_{6} \mathrm{Mo}_{7} \mathrm{O}_{24}, 10 \mu \mathrm{M} \mathrm{Fe}-\mathrm{EDTA}$, and $0.1 \mu \mathrm{M} \mathrm{NiCl}$ [21] [23].

Hoagland solution was supplemented with four concentrations of $\mathrm{Ca}(25,50$, and $100 \mathrm{mM}$ ), and Hoagland solution served as the control. To avoid root hypoxia, oxygen was supplied by a pump (Elite ${ }^{\circledast} 802$ ). The roots were pretreated with $10 \mathrm{mM} \mathrm{H}_{2} \mathrm{O}_{2}$ for 8 hours. Plants were conditioned again in the nutrient solution containing the corresponding treatment for one week. The average $\mathrm{CO}_{2}$ level in the experiment was $502 \mathrm{ppm}$. The relative humidity was $37 \%$, and the temperature was $23^{\circ} \mathrm{C}$ (WatchDog model A160 temp/HR/CO ${ }_{2}$, Spectrum Technologies Inc.).

\subsection{Experiment I}

\subsubsection{Stem Diameter, SPAD, Root Length and Length Stem}

The growth variable was evaluated 15 days after incubating at different concentrations of $\mathrm{Ca}\left(\mathrm{NO}_{3}\right)_{2}$. For the stem diameter (DT) it was measured with a digital vernier $(\mathrm{mm})$ and was the average of three measurements on the stem (low, medium and upper). The value of the SPAD readings was the average of three readings per plant; it was performed using a SPAD-502 meter (Konica-Minolta, Japan). Plant length (LP) was measured with a graduated ruler $(\mathrm{cm})$ from the base of the stem to the apex. Root length (LR) was measured with a graduated ruler $(\mathrm{cm})$ from the base of the stem to the most distal part of the root.

\subsubsection{Fresh and Dried Root, Stem and Leaf Biomass}

After evaluating the growth variables, the roots, stem and leaves of the seedlings were separated, subsequently labeled and weighed. The root, stem and leaf were placed in an oven (Felissa, model Fe-292 AD) at $60^{\circ} \mathrm{C}$ for 72 hours. Fresh and dried biomass was weighed on a RADWAG ${ }^{\circ}$ AS 310/X precision balance. 


\subsection{Experiment II}

\subsubsection{Root Immersion in $\mathrm{H}_{2} \mathrm{O}_{2}$}

Once the first experiment is evaluated, and before preparing and adding the Hoagland solution with the different concentrations of $\mathrm{Ca}$. To each tray, containing distilled water was added $10 \mathrm{mM}$ hydrogen peroxide $\left(\mathrm{H}_{2} \mathrm{O}_{2}\right)$ and temporarily left for 8 hours with the oxygenation system with tomato seedlings. Subsequently, the Hoagland solution was renewed with calcium concentrations. Seven days later, the growth variables were measured: stem diameter, SPAD value, root length and seedling length. Fresh and dried root, stem and leaf biomass.

\subsubsection{Mineral Profile in Root and Leaves Tomato Seedlings}

Once the samples of the treatments with Ca levels and peroxide treatments have been quantified. The processing of the samples was developed according to those described by García-Gaytán et al. [19] and Bautista et al. [20]: the total fresh biomass was quantified, the it was introduced in an oven (Felissa ${ }^{\circledast}$, model Fe-292 $\mathrm{AD})$ at $60^{\circ} \mathrm{C}$ for 72 hours. The resulting dry biomass weight was milled Osterizer blender. The samples, once ground, were put into capsules for a micro-grinding process. The micro-grinding was carried out in a team (Retsch, MM400) for 9.0 minutes. To obtain a pellet of the particles of the micro-grinding, the sample was subjected to a hydraulic press (Retsch, PP25) at 20 tons of pressure. The resulting tablet was placed in an aluminum mold. The relative content was determined in a scanning electron microscope (Scanning Electron Microscope, Model 7582, England), equipped with energy-dispersive spectroscopy. The value of the elementary composition corresponds to the average of three replicates between the treatments.

\subsection{Statistic Analysis}

Data were analyzed using SAS software ver. 9.3. An analysis of variance (Proc ANOVA) was performed. The comparison of means was made using the Tukey test with a significance value of $95 \%(P \leq 0.05)$ in order to determine the significant differences between the variables.

\section{Results and Discussion}

Figure 1 shows the characteristics of roots, stem, and leaves of tomato seedlings in response to Hoagland's nutrient solution, with the addition of different levels of calcium (mM). While Figure 2 shows a higher biomass of leaves and stems in the seedlings with the immersion of roots in $\mathrm{H}_{2} \mathrm{O}_{2}$. Although there is a greater abundance of root hairs, necrosis is also evident (Figure 2).

\subsection{Growth, Fresh and Dry Biomass without Peroxide Immersion}

The statistical analysis showed that root length, seedling height, stem diameter, chlorophyll content and fresh root biomass did not present statistically significant differences $(P \leq 0.001)$ with the NS or with the additions of the levels of $\mathrm{Ca}$ (Table 1). There were statistically significant differences in fresh stem and leaf 


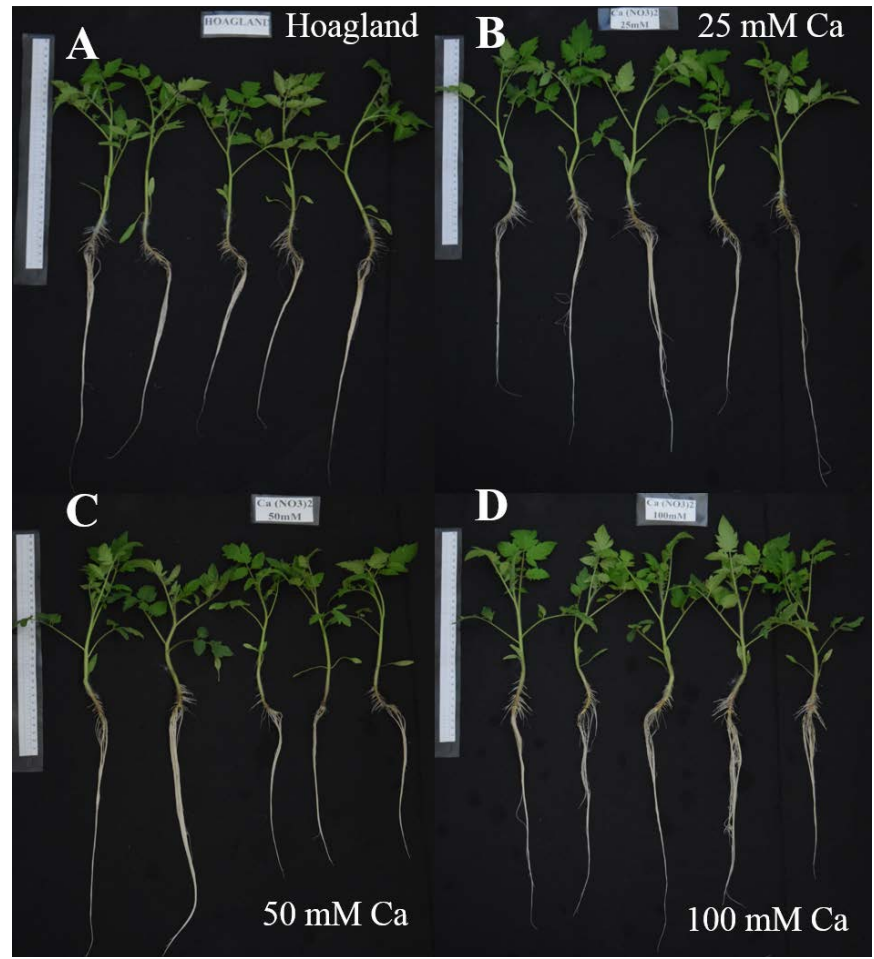

Figure 1. Tomato seedlings with different calcium levels without peroxide immersion. (A) Control; (B) $25 \mathrm{mM}$; (C) $50 \mathrm{mM}$; (D) 100 mM. Bar $30 \mathrm{~cm}$.

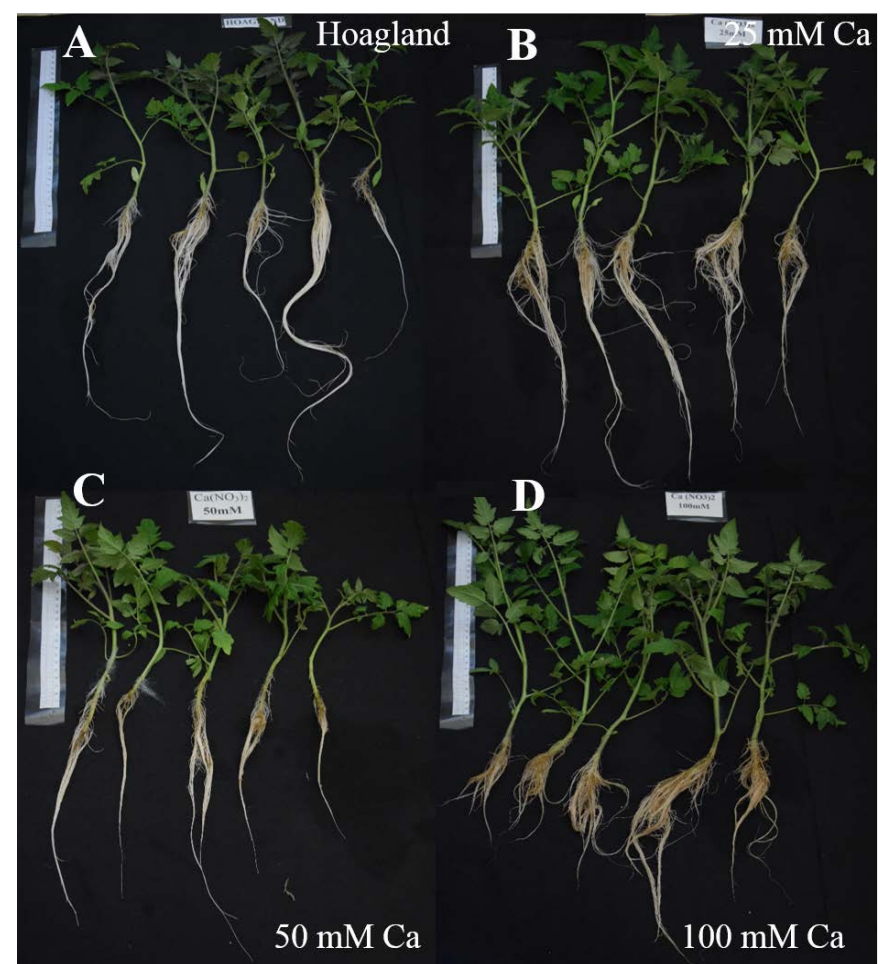

Figure 2. Tomato seedlings with different levels of calcium and immersion in peroxide for 8 hours. (A) Control; (B) $25 \mathrm{mM}$; (C) 50 $\mathrm{mM}$; (D) $100 \mathrm{mM}$. Bar $=30 \mathrm{~cm}$. 
Table 1. Nutritive solution and different levels of calcium on growth, fresh biomass and dry biomass in tomato seedlings.

\begin{tabular}{ccccccc}
\hline & \multicolumn{7}{c}{ Nutrient solution } \\
\cline { 2 - 7 } Growth variable & Control & 25 & $\begin{array}{c}50 \\
(\mathrm{mM})\end{array}$ & 100 & C.V & $P$-value \\
\hline Length root $(\mathrm{cm})$ & $26.98 \mathrm{a}$ & $29.74 \mathrm{a}$ & $24.98 \mathrm{a}$ & $26.64 \mathrm{a}$ & 17.61 & 0.86 \\
Plant length $(\mathrm{cm})$ & $19.72 \mathrm{a}$ & $20.08 \mathrm{a}$ & $16.12 \mathrm{~b}$ & $17.62 \mathrm{ab}$ & 7.61 & 8.81 \\
Stem diameter $(\mathrm{mm})$ & $4.12 \mathrm{a}$ & $4.13 \mathrm{a}$ & $3.37 \mathrm{a}$ & $4.69 \mathrm{a}$ & 13.43 & 2.22 \\
Chlorophyll (SPAD index) & $34.66 \mathrm{a}$ & $39.12 \mathrm{a}$ & $31.20 \mathrm{a}$ & $38.40 \mathrm{a}$ & 13.35 & 2.93 \\
Fresh biomass of root $(\mathrm{g})$ & $0.82 \mathrm{a}$ & $0.99 \mathrm{a}$ & $1.36 \mathrm{a}$ & $0.93 \mathrm{a}$ & 51.13 & 0.95 \\
Fresh biomass of stem $(\mathrm{g})$ & $2.17 \mathrm{ab}$ & $2.48 \mathrm{ab}$ & $1.68 \mathrm{~b}$ & $2.89 \mathrm{a}$ & $22.44^{* * *}$ & 4.34 \\
Fresh biomass of leaves $(\mathrm{g})$ & $1.41 \mathrm{~b}$ & $1.66 \mathrm{ab}$ & $1.47 \mathrm{ab}$ & $2.31 \mathrm{a}$ & $27.60^{* * *}$ & 3.79 \\
Dry biomass of leaves $(\mathrm{g})$ & $0.15 \mathrm{a}$ & $0.22 \mathrm{a}$ & $0.13 \mathrm{a}$ & $0.23 \mathrm{a}$ & 52.62 & 1.16 \\
Dry biomass of stem $(\mathrm{g})$ & $0.09 \mathrm{a}$ & $0.11 \mathrm{a}$ & $0.15 \mathrm{a}$ & $0.13 \mathrm{a}$ & 79.86 & 0.38 \\
Dry biomass of root $(\mathrm{g})$ & $0.02 \mathrm{a}$ & $0.03 \mathrm{a}$ & $0.03 \mathrm{a}$ & $0.03 \mathrm{a}$ & 49.74 & 0.20 \\
\hline
\end{tabular}

Means followed by different letters in each column indicate significant differences among treatments $\left({ }^{* * *} P \leq\right.$ $\left.0.001 ;{ }^{* *} P \leq 0.01\right)$. C.V coefficient of variation.

biomass when $100 \mathrm{mM} \mathrm{Ca}$ was added to the $\mathrm{SN}$, the increase was $25 \%$ and $38 \%$ compared to the control (Table 1). There were no significant statistical differences $(P \leq 0.001)$ between treatments with the variables dry biomass of leaves, stem and root (Table 1$)$.

\subsection{Multielemental Microanalysis in Leaves, without Peroxide Immersion}

In the multi-elemental microanalysis for the leaves, only nine nutrients (macroand micronutrients) were detected among the treatments (Table 2). Statistical analysis showed that there were no statistically significant differences for $\mathrm{C}, \mathrm{O}$, $\mathrm{N}, \mathrm{P}, \mathrm{K}, \mathrm{Mg}$, and $\mathrm{S}$ with NS and the different levels of $\mathrm{Ca}$ (Table 2). However, it was observed that as the level of $\mathrm{Ca}(100 \mathrm{mM})$ in the NS increased, the Ca content in the leaf increased by $34.50 \%$ compared to the control treatment (Table 2). There were statistically significant differences $(P \leq 0.001)$ for $\mathrm{Cl}$, since with the addition of $50 \mathrm{mM} \mathrm{Ca}$ in the NS, it increased by $13.15 \%$ compared to the control.

\subsection{Growth, Fresh and Dry Biomass, with Peroxide Immersion}

The statistical analysis showed that the immersion of roots in peroxide in a period of 8 hours had no effect on the variable root length, stem diameter, chlorophyll content, fresh root biomass and fresh stem biomass (Table 3). There were statistically significant differences in seedling height, with the $25 \mathrm{mM}$ Ca treatment, the increase was $19.75 \%$ compared to the control. There were statistically significant differences for the fresh biomass of leaves with $100 \mathrm{mM} \mathrm{Ca}$, the increase was $60.80 \%$ compared to the control (Table 3 ). There were no statistically significant differences for the variables of dry biomass of leaf, stem, and root. A 
Table 2. Mineral nutrients in leaves due to the effect of different levels of calcium.

\begin{tabular}{ccccccc}
\hline \multirow{7}{*}{$\begin{array}{c}\text { Leaf mineral } \\
\text { nutrients }\end{array}$} & Control & 25 & $\begin{array}{c}50 \\
(\mathrm{mM})\end{array}$ & $\mathbf{1 0 0}$ & $\mathrm{C} . \mathrm{V}$ & $P$-value \\
\cline { 2 - 7 } & & & & & \\
\hline $\mathrm{C}(\%)$ & $49.66 \mathrm{a}$ & $49.96 \mathrm{a}$ & $49.38 \mathrm{a}$ & $48.71 \mathrm{a}$ & 1.79 & 1.07 \\
$\mathrm{O}(\%)$ & $41.09 \mathrm{a}$ & $41.13 \mathrm{a}$ & $39.78 \mathrm{a}$ & $41.43 \mathrm{a}$ & 1.71 & 3.56 \\
$\mathrm{~N}(\%)$ & $3.00 \mathrm{a}$ & $3.05 \mathrm{a}$ & $3.56 \mathrm{a}$ & $3.69 \mathrm{a}$ & 15.58 & 1.39 \\
$\mathrm{P}(\%)$ & $0.71 \mathrm{a}$ & $0.56 \mathrm{~b}$ & $0.75 \mathrm{a}$ & $0.41 \mathrm{c}$ & 8.20 & 29.08 \\
$\mathrm{~K}(\%)$ & $2.51 \mathrm{a}$ & $1.98 \mathrm{~b}$ & $2.78 \mathrm{a}$ & $1.91 \mathrm{~b}$ & 5.49 & 32.90 \\
$\mathrm{Ca}(\%)$ & $1.86 \mathrm{c}$ & $2.33 \mathrm{~b}$ & $2.52 \mathrm{ab}$ & $2.84 \mathrm{a}$ & $5.90^{* * *}$ & 25.46 \\
$\mathrm{Mg}(\%)$ & $0.36 \mathrm{a}$ & $0.35 \mathrm{a}$ & $0.40 \mathrm{a}$ & $0.29 \mathrm{a}$ & 15.13 & 2.19 \\
$\mathrm{~S}(\%)$ & $0.26 \mathrm{a}$ & $0.26 \mathrm{a}$ & $0.31 \mathrm{a}$ & $0.25 \mathrm{a}$ & 17.11 & 0.86 \\
$\mathrm{Cl}(\%)$ & $0.33 \mathrm{ab}$ & $0.26 \mathrm{bc}$ & $0.38 \mathrm{a}$ & $0.21 \mathrm{c}$ & $14.07^{* * *}$ & 9.10 \\
\hline
\end{tabular}

Means followed by different letters in each column indicate significant differences among treatments ${ }^{* * *} P \leq$ $\left.0.001 ;{ }^{* *} P \leq 0.01\right)$. C.V coefficient of variation.

Table 3. Nutritive solution and different levels of calcium on growth, fresh biomass and dry biomass in tomato seedlings with peroxide immersion.

\begin{tabular}{ccccccc}
\hline & \multicolumn{7}{c}{ Nutrient Solution } \\
\cline { 2 - 7 } Growth variable & Control & 25 & $\begin{array}{c}50 \\
(\mathrm{mM})\end{array}$ & 100 & C.V & $P$-value \\
\hline Length root $(\mathrm{cm})$ & $31.14 \mathrm{a}$ & $33.80 \mathrm{a}$ & $21.42 \mathrm{a}$ & $26.88 \mathrm{a}$ & 24.98 & 2.31 \\
Plant length $(\mathrm{cm})$ & $19.50 \mathrm{ab}$ & $24.30 \mathrm{a}$ & $16.80 \mathrm{~b}$ & $22.08 \mathrm{ab}$ & $12.54^{* * *}$ & 6.34 \\
Stem diameter $(\mathrm{mm})$ & $4.15 \mathrm{a}$ & $4.66 \mathrm{a}$ & $4.18 \mathrm{a}$ & $5.02 \mathrm{a}$ & 18.61 & 1.99 \\
Chlorophyll (SPAD index) & $39.92 \mathrm{a}$ & $43.44 \mathrm{a}$ & $36.27 \mathrm{a}$ & $50.38 \mathrm{a}$ & 18.26 & 1.07 \\
Fresh biomass of root $(\mathrm{g})$ & $2.44 \mathrm{a}$ & $3.73 \mathrm{a}$ & $1.39 \mathrm{a}$ & $5.64 \mathrm{a}$ & 3.42 & 57.69 \\
Fresh biomass of stem $(\mathrm{g})$ & $3.14 \mathrm{ab}$ & $5.09 \mathrm{a}$ & $2.70 \mathrm{~b}$ & $7.21 \mathrm{a}$ & 34.11 & 6.69 \\
Fresh biomass of leaves $(\mathrm{g})$ & $1.41 \mathrm{~b}$ & $3.06 \mathrm{ab}$ & $1.71 \mathrm{~b}$ & $4.52 \mathrm{a}$ & $33.76^{* * *}$ & 7.11 \\
Dry biomass of leaves $(\mathrm{g})$ & $0.28 \mathrm{a}$ & $0.46 \mathrm{a}$ & $0.21 \mathrm{a}$ & $0.60 \mathrm{a}$ & 45.64 & 3.73 \\
Dry biomass of stem $(\mathrm{g})$ & $0.26 \mathrm{a}$ & $0.40 \mathrm{a}$ & $0.15 \mathrm{a}$ & $0.96 \mathrm{a}$ & 110.36 & 2.0 \\
Dry biomass of root $(\mathrm{g})$ & $0.12 \mathrm{a}$ & $0.20 \mathrm{a}$ & $0.06 \mathrm{a}$ & $0.28 \mathrm{a}$ & 58.29 & 3.70 \\
\hline
\end{tabular}

Means followed by different letters in each column indicate significant differences among treatments $\left({ }^{* * *} P \leq\right.$ $\left.0.001 ;{ }^{* *} P \leq 0.01\right)$. C.V coefficient of variation.

study by Souri and Dehnavard [24] on 17-week-old tomato plants found that Ca nitrate significantly affected plant height, leaf area, and number of lateral roots compared to urea, and sulfate of ammonium.

\subsection{Multielemental Microanalysis in Leaves and Root, with Peroxide Immersion}

When the roots are exposed to peroxide and then restored in nutrient solution, it was shown that those with $25 \mathrm{mM}$ Ca, carbon in leaves increased by $1.46 \%$ compared to the control and by $7.33 \%$ compared to the treatment with $50 \mathrm{mM}$ $\mathrm{Ca}$ (Table 4). There were no statistically significant differences for $\mathrm{O}$ and $\mathrm{N}$. The 
Table 4. Multielemental microanalysis in leaves and roots in tomato seedlings with roots immersion in peroxide.

\begin{tabular}{|c|c|c|c|c|c|c|}
\hline \multirow{2}{*}{$\begin{array}{l}\text { Leaf mineral } \\
\text { nutrients }\end{array}$} & \multicolumn{6}{|c|}{ Nutrient solution } \\
\hline & Control & 25 & $\begin{array}{c}50 \\
(\mathrm{mM})\end{array}$ & 100 & C.V & $P$-value \\
\hline $\mathrm{C}(\%)$ & $50.40 \mathrm{ab}$ & $51.15 \mathrm{a}$ & $47.40 \mathrm{~b}$ & $48.56 \mathrm{ab}$ & $1.75^{* * *}$ & 7.41 \\
\hline $\mathrm{O}(\%)$ & $41.03 \mathrm{a}$ & $40.67 \mathrm{a}$ & $40.93 \mathrm{a}$ & $41.91 \mathrm{a}$ & 1.08 & 3.52 \\
\hline $\mathrm{N}(\%)$ & $2.89 \mathrm{a}$ & $2.20 \mathrm{a}$ & $3.18 \mathrm{a}$ & $3.03 \mathrm{a}$ & 18.09 & 3.04 \\
\hline $\mathrm{P}(\%)$ & $0.38 \mathrm{c}$ & $0.43 \mathrm{bc}$ & $0.68 \mathrm{a}$ & $0.33 \mathrm{~b}$ & $11.37^{* * *}$ & 16.83 \\
\hline K (\%) & $1.48 \mathrm{c}$ & $1.53 \mathrm{c}$ & $2.11 \mathrm{a}$ & $1.20 \mathrm{~d}$ & $4.50^{\star \star \star}$ & 54.60 \\
\hline $\mathrm{Ca}(\%)$ & $2.36 \mathrm{c}$ & $2.85 \mathrm{bc}$ & $3.44 \mathrm{ab}$ & $4.02 \mathrm{a}$ & $8.21^{* * *}$ & 17.80 \\
\hline $\operatorname{Mg}(\%)$ & $0.39 \mathrm{a}$ & $0.30 \mathrm{a}$ & $0.32 \mathrm{a}$ & $0.34 \mathrm{a}$ & 15.81 & 1.30 \\
\hline S (\%) & $0.57 \mathrm{a}$ & $0.32 \mathrm{~b}$ & $0.23 \mathrm{~b}$ & $0.25 \mathrm{~b}$ & $8.33^{* * *}$ & 62.91 \\
\hline $\mathrm{Cl}(\%)$ & $0.32 \mathrm{abc}$ & $0.26 b c$ & $0.49 \mathrm{a}$ & $0.16 \mathrm{c}$ & $20.18^{* * *}$ & 10.68 \\
\hline $\mathrm{Fe}(\%)$ & $0.12 \mathrm{a}$ & $0.10 c$ & $0.11 \mathrm{~b}$ & $0.07 \mathrm{~d}$ & 0 & infin \\
\hline \multirow{2}{*}{$\begin{array}{l}\text { Root mineral } \\
\text { nutrients }\end{array}$} & \multicolumn{6}{|c|}{ Nutrient solution } \\
\hline & Control & 25 & $\begin{array}{c}50 \\
(\mathrm{mM})\end{array}$ & 100 & C.V & $P$-value \\
\hline $\mathrm{C}(\%)$ & 50.59 a & $50.34 \mathrm{a}$ & $50.11 \mathrm{ab}$ & $49.22 \mathrm{ab}$ & 1.19 & 4.80 \\
\hline $\mathrm{O}(\%)$ & $42.83 \mathrm{a}$ & $42.64 \mathrm{a}$ & $42.88 \mathrm{a}$ & $43.60 \mathrm{a}$ & 0.88 & 3.12 \\
\hline $\mathrm{N}(\%)$ & $2.34 \mathrm{a}$ & $2.90 \mathrm{a}$ & $3.22 \mathrm{a}$ & $2.50 \mathrm{a}$ & 19.20 & 2.0 \\
\hline P (\%) & $0.29 \mathrm{ab}$ & $0.40 \mathrm{a}$ & $0.38 \mathrm{a}$ & $0.25 \mathrm{~b}$ & 11.06 & 9.40 \\
\hline K (\%) & $2.52 \mathrm{a}$ & $2.11 b c$ & $1.98 \mathrm{c}$ & $1.32 \mathrm{~d}$ & $4.84^{\star * *}$ & 63.79 \\
\hline $\mathrm{Ca}(\%)$ & $0.34 \mathrm{~b}$ & $0.82 \mathrm{~b}$ & $0.69 \mathrm{bc}$ & $2.06 \mathrm{a}$ & $9.80^{* * *}$ & 130.86 \\
\hline $\mathrm{Mg}(\%)$ & $0.25 \mathrm{~b}$ & $0.32 \mathrm{ab}$ & $0.29 \mathrm{ab}$ & $0.42 \mathrm{a}$ & $16.11^{\star * *}$ & 5.41 \\
\hline S (\%) & $0.18 \mathrm{a}$ & $0.19 \mathrm{a}$ & $0.21 \mathrm{a}$ & $0.15 \mathrm{a}$ & 16.67 & 1.51 \\
\hline $\mathrm{Cl}(\%)$ & $0.20 \mathrm{a}$ & $0.14 \mathrm{ab}$ & $0.11 \mathrm{~b}$ & $0.09 \mathrm{~b}$ & $17.37^{\star * *}$ & 8.12 \\
\hline $\mathrm{Fe}(\%)$ & $0.05 \mathrm{~b}$ & $0.00 c$ & $0.00 \mathrm{c}$ & $0.13 \mathrm{a}$ & 0 & infin \\
\hline
\end{tabular}

Means followed by different letters in each column indicate significant differences among treatments ${ }^{* * *} P \leq$ $\left.0.001 ;{ }^{* *} P \leq 0.01\right)$. C.V coefficient of variation.

statistical analysis showed that with $50 \mathrm{mM}$ of Ca in the NS, the concentration of $\mathrm{P}$ and $\mathrm{K}$ in leaf tissue increased by $44.11 \%$ and $29.85 \%$ compared to the control (Table 4). The Ca concentration in the leaf increased with the $100 \mathrm{mM} \mathrm{Ca}$ treatment by $41.29 \%$ compared to the control (Table 4 ), and higher by $29.35 \%$ compared to the $\mathrm{Ca}$ concentration in the treatment without peroxide immersion (Table 2). There were no significant differences for $\mathrm{Mg}$ and $\mathrm{Cl}$ between treatments. The $\mathrm{S}$ and $\mathrm{Fe}$ in leaf tissue was significantly higher in the control treatment by $56.14 \%$ and $8.33 \%$ compared to the treatment with $100 \mathrm{mM} \mathrm{Ca}$ (Table 4).

The values in tomato roots once exposed to peroxide and its reconditioning to NS are shown in Table 4. The multielemental microanalysis detected $10 \mathrm{nu}-$ trients in the root (macro- and micronutrients). The statistical analysis showed that there were no significant statistical differences for $\mathrm{C}, \mathrm{O}, \mathrm{N}, \mathrm{P}$, and $\mathrm{S}$. The root control treatment presented significant statistical differences for $\mathrm{K}$ and $\mathrm{Cl}$, 
as it was higher by $47.61 \%$ and $55 \%$ with respect to the treatment with $100 \mathrm{mM}$ $\mathrm{Ca}$ (Table 4). The statistical analysis showed that with $100 \mathrm{mM}$ of $\mathrm{Ca}$ in the NS, the $\mathrm{Ca}$ and $\mathrm{Mg}$ in the root increased by $83.48 \%$ and $40.47 \%$ (Table 4 ).

Although, in the experiment without root immersion to peroxide, it presented statistically significant differences for fresh stem biomass and fresh leaf biomass (2.89 $\mathrm{g}$ and $2.31 \mathrm{~g}$ ) (Table 1 ). However, the values in the growth parameters and dry weights were lower than the results observed in the experiment with root immersion (Table 3), for example, $\mathrm{H}_{2} \mathrm{O}_{2}$ induced an increase in root length and seedling height in a $12.01 \%$ and $17.36 \%$ (Table 3 and Figure 2), with respect to the treatment without immersion (Table 1 and Figure 1). While $\mathrm{H}_{2} \mathrm{O}_{2}$ had a positive effect on growth, however, when tomato plants are subjected to salinity stress $(\mathrm{NaCl})$, it is accompanied by significant reductions in shoot weight, plant height and number of sheets [25].

Plants uptake and translocate nutrients from the root to the conducting vessels (xylem and phloem) [20]. Nutrients are redistributed to the entire system, and in the case of the tomato, the greatest demand for nutrients is given to developing organs such as leaves, flowers, and fruits [20].

The $\mathrm{O}$ and $\mathrm{N}$ values did not differ between the experiments with and without $\mathrm{H}_{2} \mathrm{O}_{2}$ in the leaf tissue (Table 2 and Table 4). For the case of $\mathrm{P}, \mathrm{K}$, and $\mathrm{Mg}(0.75$, $2.51,0.40 \%$ ) the concentration in foliar tissue was higher (Table 2), with respect to plants with root immersion for the same macronutrients $\mathrm{P}, \mathrm{K}$, and $\mathrm{Mg}(0.68$, 2.11 , and $0.34 \%$, respectively) (Table 4). $\mathrm{H}_{2} \mathrm{O}_{2}$ induced the concentration of $\mathrm{C}$, $\mathrm{Ca}, \mathrm{S}, \mathrm{Cl}$ and $\mathrm{Fe}(51.15 \%, 4.02 \%, 0.57 \%, 0.49 \%$ and $0.12 \%)$ in the leaves (Table 4) being higher than the same nutrients $\mathrm{C}, \mathrm{Ca}, \mathrm{S}$ and $\mathrm{Cl}(49.96,2.84,0.31$ and $0.38 \%$ ) reported in the experiment without immersion in peroxide (Table 2 ).

The majority accumulation of nutrients in the root due to the effect of immersion in $\mathrm{H}_{2} \mathrm{O}_{2}$ were $\mathrm{C}, \mathrm{O}, \mathrm{N}, \mathrm{K}, \mathrm{Ca}, \mathrm{Mg}, \mathrm{P}, \mathrm{S}, \mathrm{Cl}$, and $\mathrm{Fe}(50.59 \%, 43.60 \%, 3.22 \%$, $2.52 \%, 2.06 \%, 0.42 \%, 0.40 \%, 0.21 \%, 0.20 \%$, and $0.13 \%$, respectively). However, in this case $\mathrm{K}, \mathrm{Ca}, \mathrm{Mg}, \mathrm{S}, \mathrm{Cl}$, and Fe presented statistically significant differences (Table 4). Bautista et al. [20] performed a multi-element analysis on roots, stem/branches and leaves in cherry tomato plants in fruiting stage. They found that the concentration of mineral nutrients in roots such as $\mathrm{C}, \mathrm{O}, \mathrm{N}, \mathrm{P}, \mathrm{K}$, and $\mathrm{Ca}$, were below the values observed in roots with immersion in $\mathrm{H}_{2} \mathrm{O}_{2}$ (Table 4).

Some nutrients were below the optimal range reported, such as, $\mathrm{P}, \mathrm{K}$, and $\mathrm{Cl}$ (Table 2). The $\mathrm{N}, \mathrm{Ca}, \mathrm{Mg}$, and $\mathrm{S}$ in leaves without root immersion were within the optimal range reported (Table 2). Nutrient levels in tomato leaves during the five-leaf phenological stage were $3.0 \% \mathrm{~N}, 1.0 \% \mathrm{Ca}, 0.3 \% \mathrm{Mg}$, and $0.3 \% \mathrm{~S}$ [26]. In the case of seedlings with root immersion in $\mathrm{H}_{2} \mathrm{O}_{2}, \mathrm{~K}$ was below the optimal range reported (Table 4 ).

The $\mathrm{N}, \mathrm{P}, \mathrm{Ca}, \mathrm{Mg}$, and $\mathrm{S}$ were within the optimal range reported (Table 4), according to the values described by Hochmuth et al. [26]. For their part, Bautista et al. [20] in the multielemental profile in tomato leaves, found in their values that $\mathrm{Mg}, \mathrm{S}, \mathrm{Cl}$ and $\mathrm{Fe}$ were higher than the values reported in our experiment with and without the addition of $\mathrm{H}_{2} \mathrm{O}_{2}$ (Table 2 and Table 4). While $\mathrm{C}, \mathrm{O}, \mathrm{N}$ 
and $\mathrm{P}$ the highest values were in our experiment, possibly due to the phenological stage (seedling). According to Hartz et al. [27] the optimal ranges for the main macronutrients in tomato leaf tissue are $3.89 \% \mathrm{~N}, 0.32 \% \mathrm{P}, 2.24 \% \mathrm{~K}, 3.04 \%$ $\mathrm{Ca}, 1.25 \% \mathrm{Mg}$, and $0.97 \% \mathrm{~S}$. On the other hand, Campbell [28] reports that the optimal ranges for tomato are $3.5 \% \mathrm{~N}, 0.30 \% \mathrm{P}, 3.5 \% \mathrm{~K}, 3.0 \% \mathrm{Ca}, 0.35 \% \mathrm{Mg}$, and $0.2 \% \mathrm{~S}$ respectively.

\section{Conclusions}

From the results obtained we conclude the following:

1) The experiment with NS and with $100 \mathrm{mM}$ of $\mathrm{Ca}$, increased the fresh biomass of stem and leaf by $25 \%$ and $38 \%$ compared to the control. The addition of 100 and $50 \mathrm{mM}$ Ca to the NS significantly increased the $\mathrm{Ca}$ and $\mathrm{Cl}$ content in the leaf by $34.50 \%$ and $13.15 \%$ compared to the control.

2) The experiment with $\mathrm{H}_{2} \mathrm{O}_{2}$ and with 25 and $100 \mathrm{mM}$ of $\mathrm{Ca}$ in the NS increased the seedling height and biomass of fresh leaves. With the different levels of $\mathrm{Ca}$ in the NS increased the content of $\mathrm{C}, \mathrm{P}, \mathrm{K}, \mathrm{Ca}$ and $\mathrm{Cl}$ in the leaf tissue. With the highest Ca level in the NS, Ca and Mg increased at the root by $83.48 \%$ and $40.47 \% . \mathrm{K}$ and $\mathrm{Cl}$ increased at the root without any Ca level. With this experiment we demonstrate that multielemental microanalysis is a powerful, nondestructive, fast and accurate tool for the determination of plant nutrients.

\section{Acknowledgements}

Engineer Esteban Sánchez-Rodríguez, analyst at LADiPA.

\section{Conflicts of Interest}

The authors declare no conflict of interest regarding the publication.

\section{References}

[1] Nguyen, D., Rieu, I., Mariani, C. and van Dam, N.M. (2016) How Plants Handle Multiple Stresses: Hormonal Interactions Underlying Responses to Abiotic Stress and Insect Herbivory. Plant Molecular Biology, 91, 727-740. https://doi.org/10.1007/s11103-016-0481-8

[2] Shabani, E., Tabatabaei, S.J., Bolandnazar, S. and Ghasemi, K. (2012) Vegetative Growth and Nutrient Uptake of Salinity Stressed Cherry Tomato in Different Calcium and Potassium Level. International Research Journal of Applied and Basic Sciences, 3, 1845-1853.

[3] Tuna, A.L., Kaya, C., Ashraf, M., Altunlu, H., Yokas, I. and Yagmur, B. (2007) The Effects of Calcium Sulphate on Growth, Membrane Stability and Nutrient Uptake of Tomato Plants Grown under Salt Stress. Environmental and Experimental Botany, 59, 173-178. https://doi.org/10.1016/j.envexpbot.2005.12.007

[4] Christou, A., Manganaris, G.A., Papadopoulos, I. and Fotopoulos, V. (2013) Hydrogen Sulfide Induces Systemic Tolerance to Salinity and Non-Ionic Osmotic Stress in Strawberry Plants through Modification of Reactive Species Biosynthesis and Transcriptional Regulation of Multiple Defence Pathways. Journal of Experimental Botany, 64, 1953-1966. https://doi.org/10.1093/jxb/ert055 
[5] Schützendübel, A., Nikolova, P., Rudolf, C. and Polle, A. (2002) Cadmium and $\mathrm{H}_{2} \mathrm{O}_{2}$-Induced Oxidative Stress in Populus $\times$ canescens Roots. Plant Physiology and Biochemistry, 40, 577-584. https://doi.org/10.1016/S0981-9428(02)01411-0

[6] El-Banna, M.F. and Abdelaal, K.A. (2018) Response of Strawberry Plants Grown in the Hydroponic System to Pretreatment with $\mathrm{H}_{2} \mathrm{O}_{2}$ before Exposure to Salinity Stress. Journal of Plant Production, 9, 989-1001. https://doi.org/10.21608/jpp.2018.36617

[7] Lum, H.K., Butt, Y.K.C. and Lo, S.C.L. (2002) Hydrogen Peroxide Induces a Rapid Production of Nitric Oxide in Mung Bean (Phaseolus aureus). Nitric Oxide, 6, 205-213. https://doi.org/10.1006/niox.2001.0395

[8] Guerrero-Molina, M.F., Lovaisa, N.C., Salazar, S.M., Díaz-Ricci, J.C. and Pedraza, R.O. (2014) Elemental Composition of Strawberry Plants Inoculated with the Plant Growth-Promoting Bacterium Azospirillum brasilense REC 3, Assessed with Scanning Electron Microscopy and Energy Dispersive X-Ray Analysis. Plant Biology, 16, 726-731. https://doi.org/10.1111/plb.12114

[9] Bremner, J.M. (1965) Total Nitrogen. Methods of Soil Analysis: Part 2 Chemical and Microbiological Properties, Number 9 in Series Agronomy. American Society of Agronomy Inc., Madison, 1149-1178.

https://doi.org/10.2134/agronmonogr9.2.c32

[10] Nelson, D.W. and Sommers, L.E. (1973) Determination of Total Nitrogen in Plant Material. Agronomy Journal, 65, 109-112. https://doi.org/10.2134/agronj1973.00021962006500010033x

[11] Yeomans, J.C. and Bremner, J.M. (1988) A Rapid and Precise Method for Routine Determination of Organic Carbon in Soil. Communications in Soil Science and Plant Analysis, 19, 1467-1476. https://doi.org/10.1080/00103628809368027

[12] Nelson, D.W. and Sommers, L.E. (1996) Total Carbon, Organic Carbon, and Organic Matter. In: Sparks, D.L., et al., Eds., Methods of Soil Analysis. Part 3 Chemical Methods, SSSA Book Series No. 5, SSSA and ASA, Madison, 961-1010. https://doi.org/10.2136/sssabookser5.3.c34

[13] Janusa, M.A. and Beck, J.N. (2002) Recent Applications of Flame Atomic Absorption Spectrometry to Environmental Measurements. Applied Spectroscopy Reviews, 37, 137-186. https://doi.org/10.1081/ASR-120006043

[14] Pröfrock, D. and Prange, A. (2012) Inductively Coupled Plasma-Mass Spectrometry (ICP-MS) for Quantitative Analysis in Environmental and Life Sciences: A Review of Challenges, Solutions, and Trends. Applied Spectroscopy, 66, 843-868. https://doi.org/10.1366/12-06681

[15] García-Gaytán, V., Trejo-Téllez, L.I., Gómez-Merino, F.C., García-Morales, S., Tejeda-Sartorius, O., Ramírez-Martínez, M. and Delgadillo-Martínez, J. (2018) Gamma Radiation and Osmotic Potential of the Nutrient Solution Differentially Affect Macronutrient Concentrations, $\mathrm{pH}$ and EC in Chilhuacle Pepper Fruits. Journal of Radioanalytical and Nuclear Chemistry, 315, 145-156. https://doi.org/10.1007/s10967-017-5655-6

[16] Wilschefski, S.C. and Baxter, M.R. (2019) Inductively Coupled Plasma Mass Spectrometry: Introduction to Analytical Aspects. The Clinical Biochemist Reviews, 40, 115. https://doi.org/10.33176/AACB-19-00024

[17] Goldstein, J.I, Newbury, D.E., Joy, D.C., Lyman, C.E., Echlin, P., Lifshin, E., Sawyer, L. and Michael, J. (2003) Scanning Electronmicroscopy and X-Ray Microanalysis. 3rd Edition, Springer, New York. https://doi.org/10.1007/978-1-4615-0215-9

[18] Newbury, D.E. and Ritchie, N.W. (2013) Is Scanning Electron Microscopy/Energy Dispersive X-Ray Spectrometry (SEM/EDS) Quantitative? Scanning, 35, 141-168. 
https://doi.org/10.1002/sca.21041

[19] García-Gaytán, V., Bojórquez-Quintal, E., Hernández-Mendoza, F., Tiwari, D.K., Corona-Morales, N. and Moradi-Shakoorian, Z. (2019) Polymerized Silicon $\left(\mathrm{SiO}_{2} \cdot \mathrm{nH}_{2} \mathrm{O}\right)$ in Equisetum Arvense: Potential Nanoparticle in Crops. Journal of the Chilean Chemical Society, 64, 4298-4302. https://doi.org/10.4067/s0717-97072019000104298

[20] Bautista, J., Hernández-Mendoza, F. and García-Gaytán, V. (2020) Impact on Yield, Biomass, Mineral Profile, $\mathrm{pH}$, and Electrical Conductivity of Cherry Tomato Fruit Using a Nutrient Solution and a Silicon-Based Organomineral Fertilizer. Advances in Agriculture, 2020, Article ID: 8821951. https://doi.org/10.1155/2020/8821951

[21] Jain, D., Kour, R., Bhojiya, A.A., Meena, R.H., Singh, A., Mohanty, S.R. and Ameta, K.D. (2020) Zinc Tolerant Plant Growth Promoting Bacteria Alleviates Phytotoxic Effects of Zinc on Maize through Zinc Immobilization. Scientific Reports, 10, Article No. 13865. https://doi.org/10.1038/s41598-020-70846-w

[22] Epstein E. (1972) Mineral Nutrition of Plants: Principles and Perspectives. John Wiley, New York, NY, USA, 412.

[23] Hoagland, D.R. and Arnon, D.I. (1950) The Water-Culture Method for Growing Plants without Soil. 2nd Edition, Circular 347, California Agricultural Experiment Station.

[24] Souri, M.K. and Dehnavard, S. (2018) Tomato Plant Growth, Leaf Nutrient Concentrations and Fruit Quality under Nitrogen Foliar Applications. Advances in Horticultural Science, 32, 41-47.

[25] Mohammad, M., Shibli, R., Ajlouni, M. and Nimri, L. (1998) Tomato Root and Shoot Responses to Salt Stress under Different Levels of Phosphorus Nutrition. Journal of Plant Nutrition, 21, 1667-1680. https://doi.org/10.1080/01904169809365512

[26] Hochmuth, G., Maynard, D., Vavrina, C., Hanlon, E. and Simonne, E. (2004) Plant Tissue Analysis and Interpretation for Vegetable Crops in Florida. UF/IFAS Extension, Gainesville.

[27] Hartz, T.K., Miyao, E.M. and Valencia, J.G. (1998) DRIS Evaluation of the Nutritional Status of Processing Tomato. HortScience, 33, 830-832. https://doi.org/10.21273/HORTSCI.33.5.830

[28] Campbell, C. (2000) Reference Sufficiency Ranges for Plant Analysis in the Southern Region of the United States. 